\title{
Success and Performance Measures of Industrial Companies Based on Balanced Scorecard
}

\author{
Jaroslava Kádárová ${ }^{1, *}$ and Michaela Kočišová ${ }^{2}$ \\ ${ }^{1}$ Technical University of Košice, Faculty of Mechanical Engineering, Institute of Industrial Engineering and Management, Slovakia \\ ${ }^{2}$ Technical University of Košice, Faculty of Mechanical Engineering, Slovakia
}

Abstract: Companies exist or are created mainly because of the achievement of one or more strategic goals. To ensure continued success, they should monitor its performance with respect to them. In practice the performance of a company is often evaluated by estimating its performance indicators. This paper discusses the company's performance management cycle and production performance evaluation system, which is based on the internal processes of an industrial company.

Keywords: performance measures; industrial companies; Balanced Scorecard.

\section{Introduction}

Businesses have become more and more widespread and diverse and aim their strategies for enhancing the long term growth, success and performance (Figure 1).

As a production process becomes more complex, the availability and exchange of information become more critical to the efficiency of the business. The correlation of planning, production, sourcing, distribution, finance and work force information in near real time is a proven way to empower both management and staff to reduce errors and increase production efficiency. People are often talking about different ways of business performance measurement and control.

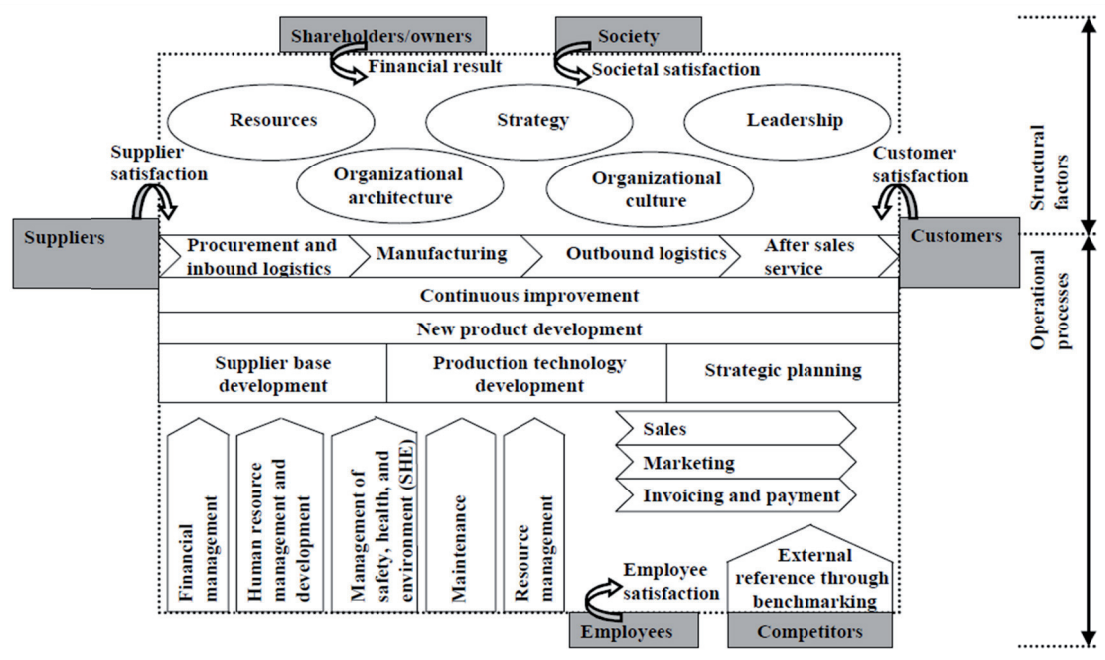

Fig. 1: A business model. 
With the Balanced Scorecard (BSC), business owners and top management implement company strategy into business processes (KPI, 2014). The BSC is a well-known business performance management concept and translates strategy in terms of objectives, measures and targets in the four perspective - financial, customer, learning and growth and internal processes (Kaplan \& Norton, 1996). Environmental and social aspects can also be subsumed under the four existing BSC perspectives.

\section{Business performance management}

Businesses have become more and more widespread and diverse and aim their strategies for enhancing the long term growth, success and performance (Lavin \& Randmaa, 2012).

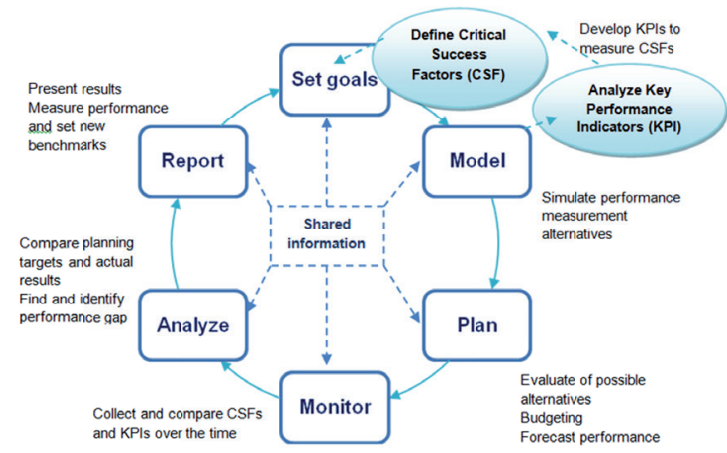

Fig. 2: An improved model of business performance management cycle.

As a product development process and production process becomes more complex, the availability and exchange of information become more critical to the efficiency of the business (Jafari, Shahanaghi, \& Tootooni, 2014). The correlation of planning, production, sourcing, distribution, finance and work force information in near real time is a proven way to empower both management and staff to reduce errors and increase production efficiency (Marr, 2010). People are often talking about different ways of business performance management (Figure 2).

This methodology implements a small feedback loop among the three major steps of performance management cycle - set goals, model, and plan (Kaplan \& Norton, 1996).

Probably the best known, the most sophisticated and in terms of implementation the most successful performance measurement system used in industrial companies and based on performance management cycle is called Balanced Scorecard (BSC). It is instrument for strategic communication which translates strategy in terms of strategic goals, success factors and performance indicators in the four main perspectives - financial, customer, learning and growth and internal processes and two another perspectives staff satisfactions, and community and environment. So, the main idea of this measurement model is linking company's financial objectives with operational aspects of business such as customers, internal processes, learning and development (Niven , 2006).

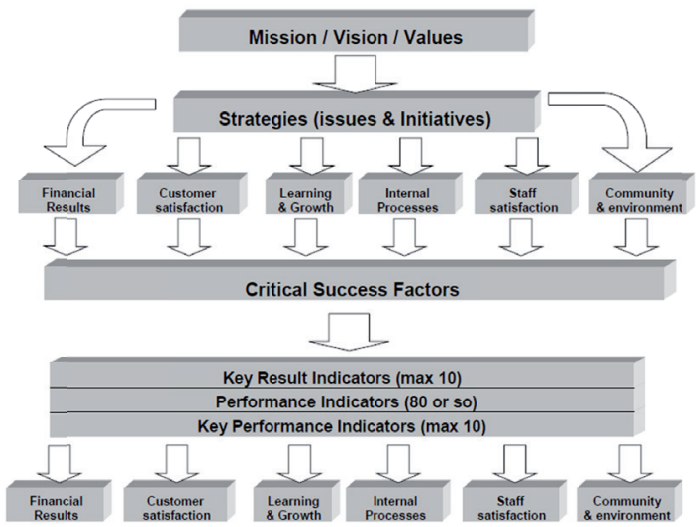

Fig. 3: Balanced Scorecard model.

According to Figure 3, industrial design of company performance starts with the company's vision, mission, strategy, objectives, and appears in performance indicators (Marr, 2015).

Company's strategic goals are based on the mission, which describes the company's main objective for existence. For reaching the goal, company may use a variety of strategies. Strategy is developed thanks to analyze of the company operating environment, which allows describing the current situation and forecasting the future. Strategy is based on the company's core purpose, core values and vision (Lavin \& Randmaa, 2012).

Unfortunately, generally and abstractly formulated vision, mission and strategic goals depend on the verbal formation, that can be influenced by wishful thinking of the management. It is important to establish connections between the development and formulation of corporate strategy and its implementation (Rovnak, 
Chovancova, \& Bednarova, 2013).

Two different strategies can be distinguished when setting objectives and formulating strategy for industrial companies (Lavin \& Randmaa, 2012):

- Revenue growth strategy - puts the emphasis on the market, products, customers and market segments. Origin for the revenue growth strategy development is in the sales department;

- Productivity growth strategy - puts the emphasis on the company's manufacturing operations and on improving efficiency through the optimization of manufacturing processes, and improving technologies and the response to appearing problems.

\section{Critical Success Factors}

Critical Success factors (CSFs) are the parameters which are vital for the success of a project or success of a business (Parmenter, 2008). They monitor if a company or project achieve its mission. The advantages of identifying CSFs are that they are simple to understand and they can be used in concert with strategic planning methodologies. Clarifying the priority order of CSFs, measuring results, and rewarding superior performance will improve the odds for long-term success as well (Figure 4).

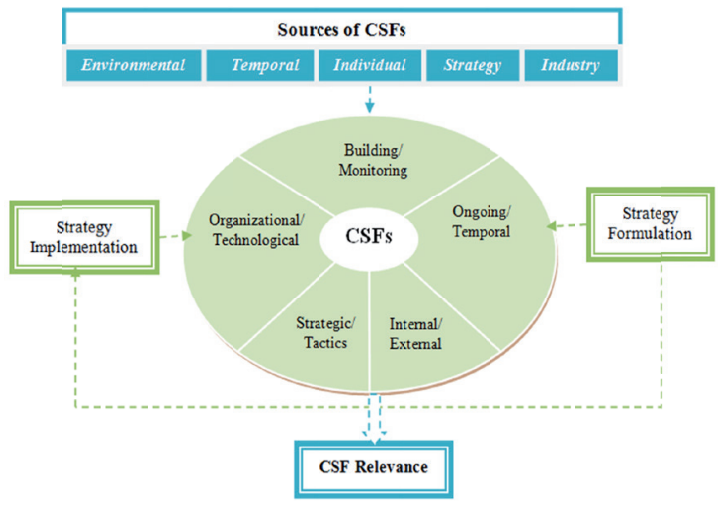

Fig. 4: Sources of CSFs.

\section{Key Performance Indicators}

Key performance indicators (KPIs) are quantifiable measurements that reflect the critical success factors of a project or business. KPIs are measures that quantify objectives and enable the measurement of strategic performance. They reflect the CSFs of a company. The application of KPI provides business executives with a high- level, real-time view of the progress of a project or company (Figure 5). Types of KPIs are the following (Wagner, 2009):

- Leading - (typically financial) tell us how the company has performed in the past (revenue, cost, margin, etc.)

- Lagging - (non-financial) tell us how the organization is performing now, predict likely future financial performance (number of returns, on-time delivery, market share, etc.)

- Input - measure assets and resources invested in or used to generate business results.

- Process - measure the efficiency or productivity of a business process.

- Output - measure the financial and nonfinancial results of business activities.

- Outcome - reflect overall results or impact of the business activity in terms of generated benefits, as a quantification of performance.

- Qualitative - A descriptive characteristic or an opinion. They find out by customer or employee satisfaction through surveys. While the survey data itself is quantitative, the measures are based on a subjective interpretation of a customer's or employee's opinions.

- Quantitative - measurable characteristics, resulted by counting, adding, or averaging numbers. Quantitative data is most common in measurement and therefore forms the backbone of most KPIs.

- Functional - is relevant for an organizational main capability and is valid across multiple organization typed and industries.

- Industry - is specific for a particular line of operations or industry.

Careful analysis of the risk also enables the organization to convert the same to performance inputs and link them directly with the business goals and achieve higher business distinction. The Key Risk Indicators (KRI) and KPI can be made to work in direct collaboration with each other to facilitate business two different sides of the same coin. The KRI provide an early warning signal to the management regarding the impending risks involved in a particular activity, the KPI provide quantifiable inputs to enhance performance and enumerate the critical success factors vital to success in the company (Rigby D. K., 2011a).

The key risk indicators provide an early warning signal to the management regarding the impending risks involved in a particular activity, the 
key performance indicators provide quantifiable inputs to enhance performance and enumerate the critical success factors vital to success in an organization (Rigby \& Bilodeau, 2011). KRI and KPI, both are vital to company planning and objective strategy along with the CSF and hence, must be accounted for in the designing the long term plans of the company (Nývltová \& Marinič, 2010).

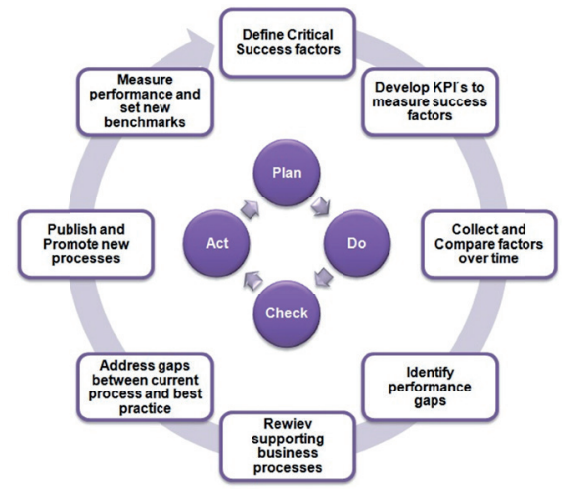

Fig. 5: KPl Identification Process.

To help select appropriate KPIs, company should create a KPI assessment template (Table 1) that lists information of KPIs, how they affect the project, and how you can ensure meet the targets. 20-point Indicator Design Template has been created and used successfully in many companies.

The first four elements of the performance indicator design template address the purpose of the indicator. Then we look at some basics and at the more technical aspects of the data collection. Instead of just selecting any existing measurement method it is important to consider the strengths, weaknesses, and appropriateness of different data collection methods (Hudáková-Stašová \& Bajus, 2015). Targets should be:

\section{- specific and time bound,}

\section{- stretching and aspirational but achievable, \\ - based on good information.}

Than we check how well the KPI we have designed. Here we look at how well the indicator is actually measuring what it is supposed to measure, the costs versus benefits, and explore any undesirable consequences or cheating behavior this indicator might encourage.

In the final section of the indicator design template the designer of an indicator identifies the way the performance indicator is reported
Tab. 1: Key Performance Indicator template.

\begin{tabular}{|c|c|}
\hline 1 & $\begin{array}{l}\text { Strategic Objective } \\
\text { Which strategic objective is this indicator rela- } \\
\text { ting to? }\end{array}$ \\
\hline 2 & $\begin{array}{l}\text { Key Performance Question (KPQ): } \\
\text { What Question do you want to have an answer } \\
\text { to? What are our information needs? }\end{array}$ \\
\hline 3 & $\begin{array}{l}\text { Who is asking this question? Who is the informa- } \\
\text { tion customer? }\end{array}$ \\
\hline 4 & $\begin{array}{l}\text { What will they do with the information? Why are } \\
\text { they asking? }\end{array}$ \\
\hline \multicolumn{2}{|c|}{ Performance indicator basics: } \\
\hline 5 & KPI ID \\
\hline 6 & KPI Name \\
\hline 7 & KPI Owner \\
\hline \multicolumn{2}{|c|}{ How will the data be collected } \\
\hline 8 & What is the data collection method? \\
\hline 9 & What is the source of the data? \\
\hline 10 & $\begin{array}{l}\text { What is the formula / scale / assessment me- } \\
\text { thod? }\end{array}$ \\
\hline 11 & $\begin{array}{l}\text { How often, when and for how long do we col- } \\
\text { lect the data? }\end{array}$ \\
\hline 12 & Who collects the data? \\
\hline \multicolumn{2}{|c|}{ Target } \\
\hline 13 & What is the target or performance threshold(s)? \\
\hline \multicolumn{2}{|c|}{ Good measures tests } \\
\hline 14 & $\begin{array}{l}\text { How well is the indicator measuring performan- } \\
\text { ce? }\end{array}$ \\
\hline 15 & $\begin{array}{l}\text { What are the costs for collecting the data? Jus- } \\
\text { tified? }\end{array}$ \\
\hline 16 & $\begin{array}{l}\text { What dysfunctional behavior could this indica- } \\
\text { tor trigger? }\end{array}$ \\
\hline \multicolumn{2}{|r|}{ Reporting } \\
\hline 17 & $\begin{array}{l}\text { Who is the primary and secondary audience for } \\
\text { this indicator }\end{array}$ \\
\hline 18 & $\begin{array}{l}\text { Reporting frequency (when and for how long } \\
\text { will this indicator be reported?) }\end{array}$ \\
\hline 19 & $\begin{array}{l}\text { Reporting channel (which channels will be used } \\
\text { to report this indicator?) }\end{array}$ \\
\hline 20 & $\begin{array}{l}\text { Reporting formats (in which formats will the in- } \\
\text { formation be reported?) }\end{array}$ \\
\hline
\end{tabular}

(Mixtaj, Nascakova, \& Weiss, 2012). It identifies the audience, access restrictions, the reporting frequency, the reporting channels and reporting formats. 


\section{Conclusions}

Key Performance Indicators are one of the most powerful tools available to enable companies to achieve performance improvement which should be a core goal of any performance management system. But using KPls appropriately comes replete with challenges. KPIs should be primarily deployed for learning and improvement and not for command control. When KPIs are used inappropriately they also become the most resisted of management tools.

\section{Acknowledgments \\ This contribution is the result of the projects implementation: Project VEGA 1/0741/16 Controlling innovation of the industrial companies for the sustaining and improving their competitiveness. \\ This contribution is the result of the projects implementation: Project KEGA 026TUKE-4/2017 Implementation of innovative educational approaches and tools to enhance the development of the core competencies graduate study program Industrial Engineering.}

\section{References and Notes}

[1] Hudáková-Stašová, L., \& Bajus, R. (2015). Cost management using the activity based costing model. Actual problems of economics, 164(2), 373-387.

[2] Hudáková-Stašová, L., \& Bajus, R. (2015). Process controlling and its software solution. Actual problems of economics, 3(165), 492-503.

[3] Jafari, M., Shahanaghi, K., \& Tootooni, M. (2014). Developing a Robust Strategy Map in Balanced Scorecard Model Using Scenario Planning. (Hindawi, Ed.) Mathematical Problems in Engineering, 1-9.

[4] Kaplan, R. S., \& Norton, D. P. (1996). Translating Strategy Into Action: The Balanced Scorecard (1 ed.). Boston: Harvard Business Scool Press.

[5] KPI. (2014). On Key Performance Indicators (KPIs), KPIs... naturally, Australia. (smart KPIs, Ed.) Cit. 2015. Dostupné na Internete: http://www.smartkpis.com/key-performanceindicator-KPI

[6] Lavin, J., \& Randmaa, M. (2012). 8th International Conference of DAAAM Baltic Industrial Engineering. Relations between business objectives and the actual outcome of the business, (pp. 19-21). Tallinn, Estonia.

[7] Marr, B. (2010, June 6). How to Design Key Performance Indicators, API White Paper. Retrieved 2015, from http://www. ap-institute.com/media/3970/how_to_design_key_performance_indicators_indicators.pdf

[8] Marr, B. (2015). What is a Key Performance Indicator (KPI)?,
Key Performance Indicators. (A. BWMC, Ed.) Retrieved from http://www.ap-institute.com/Key\%20Performance\%20Indicators.html

[9] Mixtaj, L., Nascakova, J., \& Weiss, E. et al. (2012). Evaluation of return on investment for proposed use of solar systems in Poland. Metallurgy \& Metallurgical Engineering, 51(3), 361364.

[10] Niven, R. P. (2006). Balanced Scorecard: Step by step (2 ed.). New York: John Wiley \& Sons.

[11] Nývltová, R., \& Marinič, P. (2010). Finanční řizení podniku, Moderní metódy a trendy. Praha, Cech Republic: Grada.

[12] Parmenter, D. (2008). Klíčové ukazatele výkonnosti: Rozvíjení, implementování a využívání vítězných klíčových ukazatelů výkonnosti. Česká společnost pro jakost. (1, Ed.) Praha, Cech Republic: Grada.

[13] Rigby, D. K. (2011a). Management Tools 2011, An Executive's Guide, Boston. (Bain\&Company, Ed.) Retrieved from http:// www.bain.com/Images/Bain_Management_Tools_2011. pdf

[14] Rigby, D., \& Bilodeau, B. (2011). Management Tools and Trends 2011. (Bain\&Company, Ed.) Retrieved 2015, from http://www.bain.es/management_tools/Management_ Tools_and_Trends_2011_Final_Results.pdf

[15] Rovnak, M., Chovancova, J., \& Bednarova, L. (2013). 13th International Multidisciplinary Scientific Geoconference, SGEM 2013, Book Series: International Multidisciplinary Scientific GeoConference-SGEM. Managing environmental risks in production companies, (pp. 651-658). Albena, BULGARIA.

[16] Wagner, J. (2009). Merění výkonnosti, Jak měrit, vyhodnocovat a využívat informace o podnikové výkonnosti. (1, Ed.) Praha, Cech Republic: Grada.

\section{Biographical notes}

Jaroslava Kádárová, doc. Ing. PhD.: is associate professor at the Institute of Management, Industrial and Digital Engineering, of the Faculty of Mechanical Engineering, Technical University in Košice. In 1998 she graduated at the University of Economics in Bratislava. PhD. degree received in Engineering Technologies and Materials from the Technical University of Košice in 2006. She is associate professor in Industrial Engineering from 2010 year. Her research interests include strategic, financial, and crisis management, controlling and innovations.

Michaela Kočišová Ing. PhD. MBA: is secretary of the Faculty of Mechanical Engineering, Technical University in Košice. In 2010 she graduated at the Economic Faculty Technical University in Košice. PhD. degree received in Industrial Engineering from the Technical University of Košice in 2013. Her research interests include education, strategic and financial performance, controlling and innovations. 